\title{
Problem Pressure and Social Policy Innovation: Lessons from Nineteenth-Century Germany*
}

\section{Alexander Horn and Anthony Kevins}

In studying how to best understand social program introduction, political scientists have built up a laundry list of contributory factors. We suggest, however, that "objective" problem pressure has been incorrectly neglected by many scholars in recent decades-and the well-known case of Germany's nineteenth-century introduction of social insurance legislation provides a clear illustration of this point. In explaining the origins and design of German social insurance, the interplay of three factors is key: first, exceptionally high problem pressure, connected to both labor market-and state-building processes; second, a fragile institutional context dominated by Prussia; and third, the party political constellation. In making this argument, we draw on "open functional reasoning" and extract implications from the case study to further refine the underlying theory. Specifically, we find that goal-oriented action may both be more common and more prone to compromise than the theory suggests. As such, we not only present an argument for considering the potential impact of problem pressure, but also lay out and refine an approach to doing so. In contrasting this approach to the problematic functionalism that initially inclined many scholars to neglect of problem pressure, we hope to help rehabilitate the concept-and in the process strengthen the explanatory power of research in sociology and political science.

The origins of the late-nineteenth-century social insurance legislation in Germany have long been a subject of great interest for political scientists and sociologists. In their attempts to explain Germany's status as a welfare state pioneer, authors have pointed to the role of various factors including power resources, business interests, and elite motives (e.g., Korpi 1989; Mares 2001; Ritter 1986). Within the literature on welfare states, this exercise has often served as a starting point for attempts to better understand the introduction of social programs in other countries and periods.

We continue in this tradition. Given the historical significance of this social insurance legislation - with its previously unparalleled scope marking the creation of a whole new type of intervention and the take off of welfare state development (Alber 1988; Schmitt et al. 2015: 505-6)—we return to the case to explore the question: How can we best explain radical social policy innovation? We do so with two goals in mind.

First, we believe the case highlights a blind spot in the contemporary sociological and political science literature: namely, a failure to recognize the importance of "objective" problem pressure that poses an existential threat to the system. Historians

*This article received helpful feedback from presentations made at Aarhus University and the 2015 Annual Meeting of the Danish Political Science Association in Kolding, Denmark. We are grateful to all those who provided comments on earlier drafts, and owe a particular debt of gratitude to Paul Marx, Kees Van Kersbergen, Christoffer Green-Pedersen, and our two anonymous reviewers. 
have long pointed to the impact of various types of problem pressure, both with reference to German social insurance (e.g., Frohman 2008) and more generally-for example, with dénatalité and family policy in fin-de-siècle France (Pedersen 1995), or risk exposure in European welfares states (Baldwin 1990). Yet while the classic political science literature was not averse to considering these sorts of factors (e.g., Rimlinger 1966), contemporary political science has been far more reticent (though for some recent exceptions, see Béland 2005; Hacker 1998; Hall and Thelen 2009). This is largely the result of the thorough discrediting of functionalism, which saw functional pressures as leading automatically to functional responses, thereby erasing agency in the process. Through this investigation, however, we suggest that the antifunctionalist movement in political science and sociology, while correct in its criticisms and goals, has been so thoroughly successful that something essential to understanding politicsproblem pressure-has fallen by the wayside.

But rather than simply criticizing this omission, we also explore the case to draw out theoretical implications-which serves as the second goal of our present study. This involves three steps: laying out an alternative theoretical approach, namely "open functional reasoning" (see Becker 1988, 2007, 2009; Van Kersbergen and Vis 2013; Vis and Van Kersbergen 2013), applying the theory to the case at hand, and then using the investigation to draw out potential revisions to the theory. The case study therefore serves to both relegitimize the importance of problem pressure and lay out and refine a theoretical approach to do so.

The introduction of German social insurance legislation is particularly instructive here. It acted as a pivotal source of policy diffusion to other countries (see Abbott and DeViney 1992; Schmitt et al. 2015) and, given the truly radical nature of the reform, serves as a crucial case. In explaining its origins, we discuss the interplay of three factors. First, exceptionally high problem pressure, connected to both the labor market- and state-building processes, threatened the very existence of the German Empire. As we will show, this pressure was the result of two developments: comparatively rapid industrialization, particularly in sectors associated with high occupational risk, and the failed attempts to reform the inefficient and fragmented system of private local insurance funds (i.e., the Kassen) that were often associated with the labor movement. The result was a situation in which reform was required for the continued existence of the system-though (contra certain functionalists) this does not mean that reform would take a certain form, nor indeed that it would even occur.

To understand the nature of the reform, we must consider our remaining factors: The second of these, namely the fragile institutional context dominated by Prussia and marked by asymmetrical federalism, points to the importance of institutional context, while the third highlights the party political constellation in which the statebuilder and Reichskanzler Bismarck found himself. For a variety of reasons, most parties supported the idea of social insurance in the early 1880s, but not Bismarck's centralized version of it.

Note that we focus upon these three factors not because they are the only things we need to consider to understand the introduction of German social insurance 
legislation; there is, of course, a long history of work on these policies that points to the importance of various other explanations, not least a desire to undercut socialism, remove legal loopholes in the liability laws, and correct for the various shortcomings of the preexisting poor relief system (e.g., Baldwin 1990; Frohman 2008; Hennock 2007). Rather, we seek to incorporate these various additional explanatory factors within a framework of study that is ultimately focused on problem pressure-pressure that we situate within both a precise institutional context and political circumstances characterized by distinct party dynamics. In doing so, we hope to speak specifically to an existing blind spot in social science research.

Through analyzing the case study, we argue that situating the origins of social insurance legislation within a context of existential threat is central to understanding social program introduction. While we do not suggest that problem pressure was sufficient to bring about reform on its own, without it such radical policy innovation would not have occurred. What is striking about the introduction of German social insurance is the overlap between the preferences of the core actors (Bismarck and the administration, political parties, unions, business associations, etc.). Although these actors came from different ideological and social backgrounds and represented different material interests, they agreed that the traditional institutions- the Kassenwere increasingly obsolete and dysfunctional. What is more, they even converged on a similar understanding of what needed to be done. This, we think, can only be understood against the background of rapidly increasing problem pressure.

Yet, the eventual outcome was not predestined. There were clearly alternative potential policy outcomes and identifying why the eventual reform won out over others requires us - in the absence of data appropriate for quantitative analysis - to dig more deeply into the historical context (Robertson 1993). To properly understand change and the introduction of social insurance programs, we therefore employ historical analysis to unpack the interplay between problem pressure and the broader institutional context.

In making this argument, we begin by briefly laying out the meaning of open functional reasoning, which leads us to discuss some of the theoretical reasons to expect a priori that the German institutional setup might impede reform. We then proceed to the historical analysis, beginning by describing key characteristics of the institutional context in the German Empire. We then discuss both the problem pressure and the politics behind the government's insurance legislation, drawing out some lessons for the broader literature. Finally, we conclude by stressing the crucial (yet oft-neglected) role of problem pressure as an important contextual factor and exploring some of the theoretical refinements to open functional reasoning that are suggested by the investigation.

\section{Problem Pressure and Barriers to Reform}

Functionalism, which often treated the fulfillment of objective imperatives as automatic, or as a process with automatic consequences, is of course deeply 
problematic-reducing humans to mere pawns, lacking in free will and decisionmaking capacity. And yet, we argue that there are many real-life instances in which ignoring problem pressure (as a sort of antifunctionalist reflex) obscures a central contextual factor. The result is a weakened ability to both describe and explain policy change.

In making this case, we begin by defining open functional logic and distinguishing it from functionalism. Here Becker (1988)-building on earlier work taking an open systems perspective (e.g., Demerath 1966; Luhmann 1984)—serves as our starting point. Against functionalists (e.g., Parsons 1977; Wilensky 1975; Wilensky and Lebeaux 1959), he argues that functional logic can only be applied in "objective" instances of "general existential necessities of social life, existing independently of human knowledge and of special interests, and involving certain functional exigencies people are forced to meet" (Becker 1988: 875). "Objectivity" therefore relies on the existence of an existential threat, defined by the potential collapse of a system. "Subjective" goals, by contrast, are dependent on political preferences, and their accomplishment is not necessary for system maintenance (see Becker 2009: 25). Of course, politicians may well, for political purposes, take to defining "subjective" goals as "objective" ones, but this does not erase the relevance of the distinction.

As a classical example of what is meant by "objectivity" here, one may think of the maintenance of at least a certain level of profitability under capitalism-where the "objectiveness" of this requirement is defined according to the fundamental role of profitability within capitalism (Becker 1988: 876). In circumstances where profitability under capitalism is under threat, the maintenance of capitalism as a system would therefore require action, lest human subsistence under capitalism be compromised. One might prefer certain means of maintenance over others-or indeed even the collapse of the system-but these preferences are incidental to the underlying existential threat.

Although such a functional requirement could theoretically be addressed by conscious goal-directed action, Becker (ibid.: 879) argues that this is highly unlikely. There are three reasons for this: first, societal conflict over potential solutions; second, cognitive limitations that prevent humans from knowing what is functional; and third and most importantly for Becker (ibid.: 878-79), "people's inability to take into account not only their special interests but at the same time ... those existential conditions that affect everyone." As such, except for (perhaps) in a few authoritarian cases, he concludes that functional requirements are dealt with through "societal processes of trial and error ... involving learning, accommodation, compromising, and perhaps problem-solving differentiation" by actors and groups with various particular interests (ibid.: 879).

This observation points to another important contrast with functionalism as a theory: The recognition of functional pressure cannot tell us the form a solution will take, or indeed even that an adequate solution will be reached (though not all functionalists [e.g., Rimlinger 1966] were guilty of these assumptions). It is in this sense that the functional logic must be considered "open," and it is here that factors often 
pointed to by constructivists (such as ideas and agent understanding) enter the picture (see, e.g., Campbell 2002). Open functional reasoning therefore carves out a role for various other context-specific influences, such as ideational setting (Béland 2005), policy learning (Hall 1993), and blame avoidance (Van Kersbergen and Vis 2013).

From this perspective, agency remains a key component to understanding developments. Agents are ultimately responsible not only for the choice to act, but also for decisions about which type of action to pursue. ${ }^{1}$ But these actions do not occur in a vacuum, and objective problem pressure is a central contextual factor. To remove problem pressure from such a case, simply for fear of lapsing into functionalism, is to miss a considerable part of what drives actors in these instances. It is here that open functional reasoning has much to offer, as we hope to demonstrate in the remaining sections.

Taking this literature as our starting point, we apply this framework to the introduction of German social insurance legislation and investigate how the case informs our understanding of open functional reasoning. The present study thus builds on previous work seeking to refine the theory and explore the fruitfulness of its application (e.g., Becker 2009; Van Kersbergen and Vis 2013; see also Crouch and Farrell 2004). In doing so, we turn first to outlining the institutional context in order to situate the remainder of the discussion, and then proceed to examine the problem pressure and the politics behind the government's insurance legislation.

\section{The Asymmetric Federalism of the Fragile German Empire}

The achievement of unification in 1871 marked the creation of a federal system in Germany, as the previously independent states joining the union were given considerable power within the newly formed German Empire. These substate powers included formal representation in the Bundesrat (the upper chamber of the national parliament); a high degree of financial autonomy, which led the central government to rely rather heavily upon the states for financing; and administrative control that resulted in the states implementing most federal legislation (Ziblatt 2006: 109-10). This federal arrangement served as an acknowledgment that the German Empire was being formed from a collection of sovereign and autonomous states, making the goal of unification more realistic (see Manow 2005: 236).

The new constitution entrenched the federal structure of the empire. States retained power over their internal affairs, while the federal government controlled internationally oriented issues and standardization (Abrams 2006: 12-13). The federal government was granted exclusive control over key "matters of importance to Germany's economic well-being," but this left a considerable sphere of power to the states, with jurisdiction over "all matters that affected the citizen's daily life and the safety and well-being of his family" (Craig 1999: 40).

The states were also able to maintain their interests at the national level through their appointed representatives in the Bundesrat, which acted as the second chamber alongside the Reichstag and its elected members. The Bundesrat had an absolute 
veto in matters directly concerning their jurisdiction or administrative resources, and had a suspensive veto in all other areas, with each state granted votes in proportion to its size (Abrams 2006: 14). This arrangement is particularly central given that the proportional system of voting in the Bundesrat gave Prussia a veto on constitutional amendments (Craig 1999: 42).

Despite the special rights the constitution granted to Bavaria (and to a lesser extent some other states), it is important not to understate the role of Prussia; in situations in which Prussia chose to lean upon its smaller client states, it was able to prevent the Bundesrat from acting contrary to its interests. Indeed, in his role as the first German Chancellor, Bismarck expressed confidence that Prussia could be relied upon to side with the federal government on basic matters (ibid.: 42). While Bismarck was de jure dependent on the Prussian King and Emperor of the Reich Wilhelm I, historians agree with Wilhelm, who said, pointing to the dominant role of the chancellor, that it was "hard to be king under Bismarck" (Steinberg 2011).

This asymmetric federalism - with a de jure blocking minority for Prussia against the southern states and its de facto role as agenda-setter through Bismarck-is a key contextual factor of the period. ${ }^{2}$ Understanding the introduction of the first social insurance programs, however, requires us to also consider changes in the nature and degree of problem pressure.

\section{Problem Pressure and the Politics of Social Policy}

The role of the empire as a vanguard in social insurance legislation must be understood as defensive modernization in at least two regards. First, the laws were necessary to address the "objective" problem pressure that had grown rapidly since the industrial takeoff began in the 1850s (North 2005), which until that point had not been addressed through appropriate policy reactions. Second, the laws were necessary to flank and complement other legislation (e.g., the shift to trade-protectionism and the antisocialist laws) in a critical phase of state building (see, e.g., Baldwin 1990: 57-58; Weindling 1991: 197). Addressing these points in turn, we show that a failure to react to the economic and political pressure that was building up would have posed an existential threat to the existing system, and that the need for reform became a shared belief among the conservative Prussian state builders and across political and class boundaries. The fact that actors with diverse interests, group linkages, and worldviews agreed on the need to introduce social insurance, even at the price of considerable compromises in its design, lends support to our interpretation that the economic and political viability of the German Empire was at stake. In other words, functional pressure paved the way for intentional policy reaction.

\section{Problem Pressure and Strategic Interests}

Industrialization in Germany was particularly rapid, partly due to the belated end of the feudal system and the late unification of the empire, which also included a 
harmonization of trade regulations and a decline in tariffs. Late German state building is thus often regarded as a precondition for what historians refer to as the "rapid" or "spectacular" economic development of the empire (Kiesewetter 1989: 137).

Between 1870 and 1913, the "economic latecomer" Germany experienced the fastest economic growth in Europe, alongside Switzerland and Denmark (North 2005: 441; Rimlinger 1966: 560). The GDP share of the primary sector sank drastically, from almost 50 percent in the 1860s to around 20 percent at the eve of World War I in 1913 (North 2005: 451). Within one decade after the founding of the empire in 1871, the proportion of industrial laborers rose from 20 to 25 percent. The "industrial reserve army" was growing, especially throughout the Franco-Prussian War and the reparation-fueled boom "founding years" (see Rosenberg 1967). This was proceeded by the bursting of a speculation bubble and a consequent credit crunch ("founder's crash"), which created an especially precarious situation for industrial laborers during the lengthy period of volatility that followed (Rosenberg 1943). This major slump, typically referred to as the Great Depression, lasted until 1896 and ushered in a period of increased state intervention in economic and social domains across Central Europe (Hentschel 1978: 205-9; North 2005; Rosenberg 1943: 70-71; Wehler 1969: 43-45).

Importantly, the most rapid growth occurred in sectors that were associated with high occupational risk. Figure 1 shows the size of the labor force in agriculture and
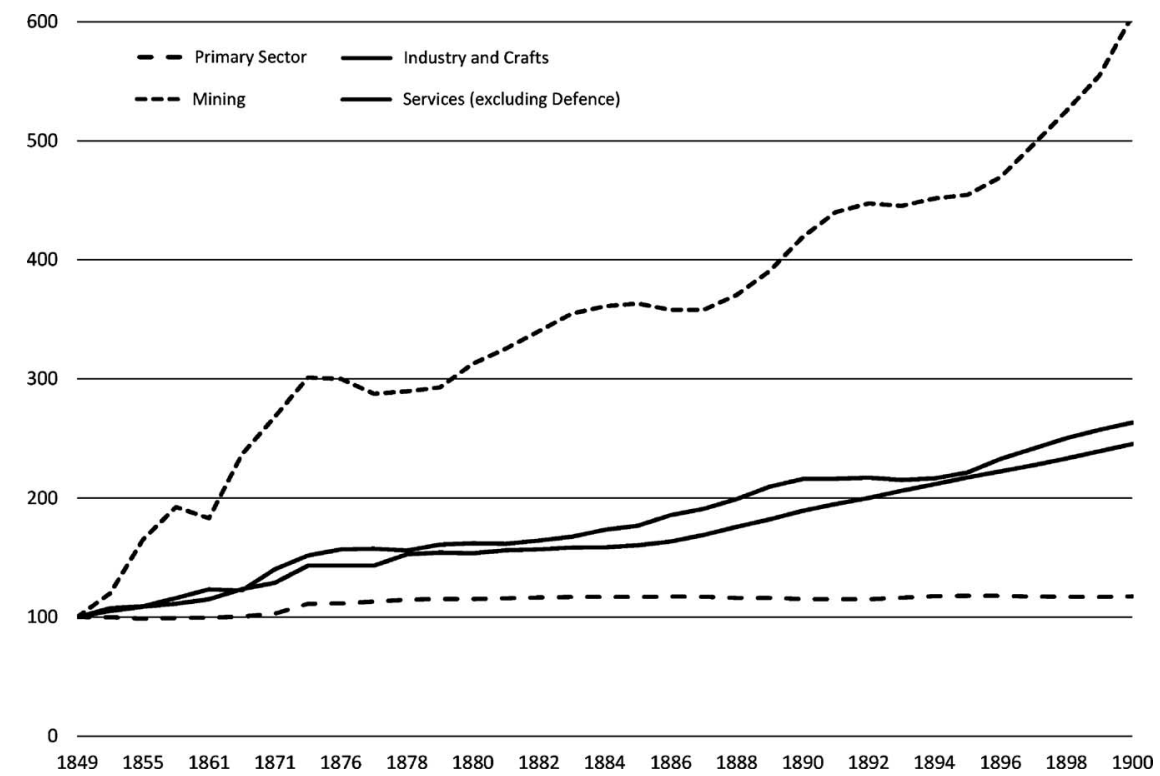

FIGURE 1. Employment in different sectors $(1849=100 \%)$.

Note: Data from Walther G. Hoffmann (1965 [2006]) Das Wachstum der deutschen Wirtschaft seit der Mitte des 19. Jahrhunderts. GESIS, GER, ZA8256 Datenfile Version 1.0. 
fishing, mining, industry and crafts, and services, taking 1849 (the earliest year for which data is available) as a base value comparison. Clearly, the high-risk sectors, especially mining, were drivers of the economic boom. Presumably, the growth of the labor force in industry, where one would find relatively higher levels of risk, was higher than in crafts, an occupational group that was exposed to lower occupational risk (available data does not differentiate within these categories). Nevertheless, it remains clear that employment in riskier sectors was on the rise, as evinced by the mining sector's especially rapid growth in the 1870 s.

To illustrate that the economy was only starting to grow rapidly from the late 1850 s onward, we also visualize labor productivity over a much longer time span. Figure 2 provides an illustration of this boom, showing the productivity trend in coal mining between 1820 and 1913 in Dortmund (national data is unfortunately unavailable). Looking at the figure, one notes that after a long period of relative stability, productivity - annual coal production per worker-increased rapidly from the 1860 s to the mid-1880s. In the wake of the boom, productivity stagnated again for 30 years until the end of our time series in 1913.

By the 1870s, the disruptive consequences of rapid industrial takeoff on the traditional social order and institutions had become fully visible. Conflicts between employers and workers became more hostile, strikes escalated more frequently, and it was increasingly acknowledged that more social cooperation was needed (QGDS 1.3: XIX-XXXIX; QGDS 1.8: XV-XIX; QGDS 1.2: 123). ${ }^{3}$ At the same time, pressures to improve worker protection grew substantially over the course of the decade (QGDS 1.2: 17; QGDS 1.3: XXII). The question of worker protection in

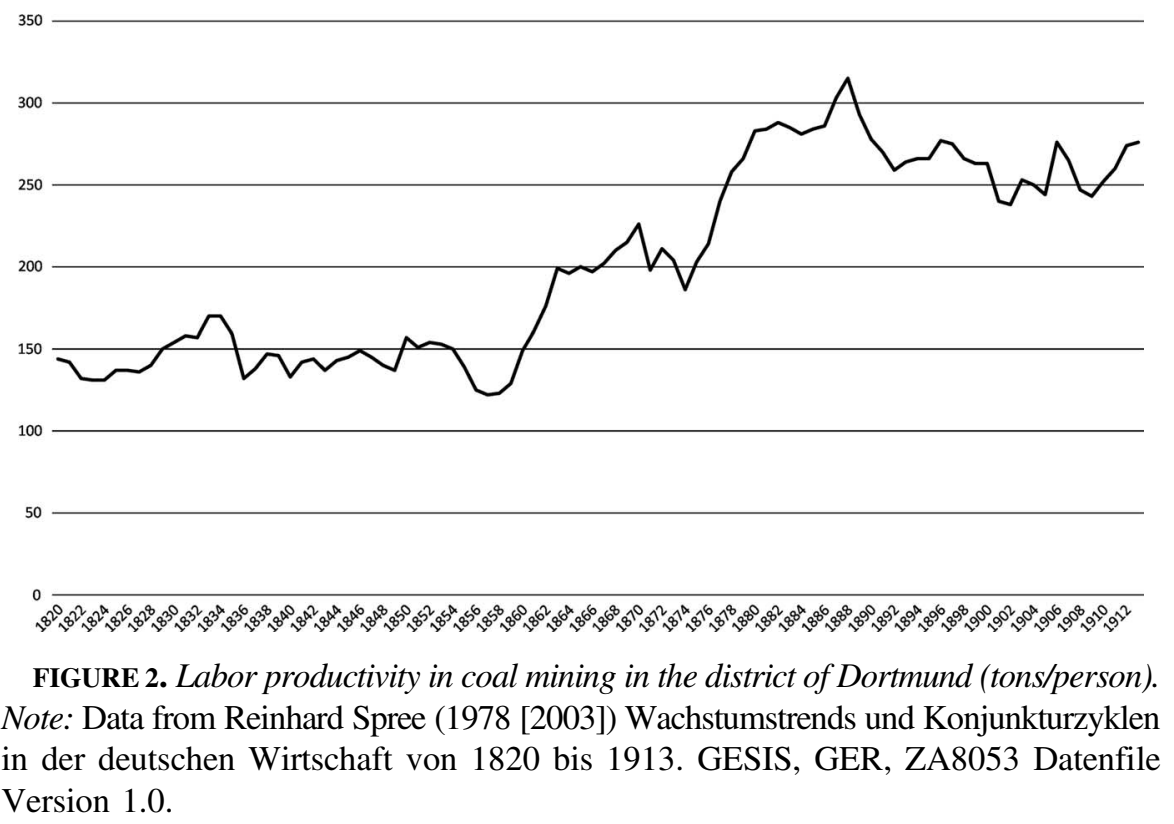


general and liability more specifically became more pressing in the aftermath of a series of spectacular accidents in factories and mines (Deutsches Historisches Museum 2010; Reidegeld 2006: 179). The old mechanisms for the provision of social care by guilds and feudal lords no longer existed and local poor relief systems were outdated, having been designed for a preindustrial era of immobile workers (Frohman 2008: 100-1; QGDS 1.6: XXI-L; QGDS 1.7: XIX-XXXIX).

What is more, several developments and failed attempts to address the problem pressure had the adverse effect of instead exacerbating it. First, a vague law introduced to determine the liabilities of employers, the so-called Reichshaftpflichtgesetz/ "imperial liability law" (Reichsgesetzblatt Nr. 25) from 1871 did not alleviate the pressure. Most problematically, the legislation applied only to some sectors and, for an employee to receive compensation, the worker was required to establish the employer's liability (Deutsches Historisches Museum 2010: 4; Frohman 2008: 103). To make matters worse, Bismarck, large parts of the bureaucracy, and most of German industry opposed factory legislation comparable to the strict rules implemented in Switzerland or England at the time (QGDS 1.1: 107, 157; QGDS 1.3: XXXII-XXXIX; QGDS 2.3: XIX-XXIX, 136, 201). As a result, only basic supervision of factories was introduced.

Consequently, debates about the desirability and behavioral consequences of holding employers liable for accidents and work-related health issues went on for much of the 1870s. Bismarck, industry elites, and those in the trade ministry viewed extended private liability as a bureaucratic and competitive burden that was bound to privilege "loafers and slackers" (QGDS 1.2: 20, 21, 56, 57, 123). A state solution (i.e., social insurance) was seen to offer a means of circumventing these debates (QGDS 1.2: 83, 117).

The most crucial factor augmenting the need to introduce rudimentary insurance programs, however, was not the gridlock in worker protection and liability, but rather the inability of the booming private and mutual self-help insurance schemes (i.e., the Kassen) to deal with the expanding number of precarious and increasingly mobile industrial workers. Indeed, these schemes had proven ineffective in a variety of ways (Bleses and Seeleib-Kaiser 2004). Although the Kassen were growing in terms of insured members and financial resources, the system was beset with various problems for workers searching for insurance (QGDS 1.5; QGDS 1.6; Reidegeld 2006: 152): first, onerous eligibility criteria made it difficult to join these funds; second, even despite these criteria, these (mostly local and regional) funds were not always solvent when crisis hit; and third, benefits and insurance premiums were often adjusted on an ad hoc basis, reflecting the absence of sound data about risk distributions, the (local) concentration of risk, and the frequent use of the funds to finance strikes (QGDS 1.5). But even setting these problems aside, the Kassen were firmly out of step with increased demands for labor mobility. Relocation to another area often entailed the loss of benefits, notwithstanding attempts to broaden the regional scope of the Kassen (Hentschel 1978; QGDS 1.5: XXIII-XXV). In sum, the traditional Kassenwesen (as the system of Kassen was called) was ill-equipped to cope with rising demand for basic insurance, especially in the face of economic crisis and increased labor mobility. 
In addition, the expanding Kassenwesen posed a direct political threat to the establishment because the Kassen were often politically left-leaning-especially after workers started to shift their allegiances from the liberals to the social democrats in the 1870s (QGDS 1.5: XXXVII). The Kassen thus served-and were perceived to serve-as an organizational and financial resource for the labor movement. In particular, the Kassen were often thought to be ideologically infiltrated, with close ties to unions, and were perceived to have played an important part in the formation of what Marx called "class consciousness" (Reidegeld 2006: 154). Indeed, the Kassen did strengthen the self-rule of labor and the capacity for self-rule by providing organizational infrastructure (QGDS 1.5: XXXV-XXXVI; Reidegeld 2006: 184).

In 1876, new legislation concerning the Kassen was implemented, and free funds with close ties to the labor movement came under stricter control of municipalities and local agencies. Rather than addressing problem pressure, however, the intention was to restrict the possibility of funds cross-subsidizing labor unions. The independent Kassen persisted but under stricter control (Reidegeld 2006: 189). Yet, this attempt to control the political dynamic and correct the system without introducing insurance was unsuccessful. This legislation also failed to bring about the desired rapid increase in insurance coverage, leading pivotal advisors (like Oberregierungsrat Theodor Lohmann) and large parts of the government to label the law a failure (QGDS 1.5: LI; QGDS 2.5: 1).

In sum, industrialization created the functional and political need for social policy adjustment by the conservative state builders, and the legislative attempts to adapt through piecemeal reforms often only exacerbated existing problems (QGDS 2.1: XVI-XVII). Few other instruments to counter the social consequences of industrialization were available; only Prussia had a regional redistribution mechanism to level regional disparities. The need for political action to address the rising problems was therefore pressing. However, the nature of the delayed reaction to the consequences of rapid industrialization can only be understood against the background of the existent political constellation.

\section{Reform Preferences and Positions}

The introduction of the insurance package is sometimes seen as an attempt by Bismarck to "shore up the fragility of the new German state" and bribe the working class to secure their support for and subservience to the empire (Abrams 2006: $40-41,46)$. But this motive, in and of itself, does not fully explain why the programs were introduced, and helps even less to understand the broad political support for reform or the eventual idiosyncratic policy outcome (i.e., the hybrid character of the first German insurance bodies as state-funded yet independent agencies). Indeed, the states and parties in the Reichstag agreed with the idea of introducing social insurance to protect workers against the consequences of accidents, sickness, and invalidity (QGDS 2.1; QGDS 2.6: XVII) - albeit not in the statist and centralized way Bismarck wanted to organize it. 
Given Bismarck's rejection of both stricter workplace safety legislation and harsher liability laws, problem pressure, if unaddressed, could have played into the hands of the labor movement. All the legal parties in parliament shared the rejection of the Social Democratic Party (at the time called the Sozialistische Arbeiterpartei Deutschlands [SAPD]), though the legal means with which Bismarck fought the labor movement were criticized occasionally by the left wing of (national) liberalism. Yet the period also saw growing political competition over workers, who had mostly voted liberal (to show their support for democracy) until the 1860s but began to branch out thereafter. Concerns about losing workers to the left became particularly pressing after the labor movement started to organize and the competing factions finally formed a common organization in 1875 with the SAPD.

Within this context, not only did most political forces agree on the necessity of alleviating the problem pressure, but there were also few genuinely antiwelfare state positions. Here, consulting election manifestos is instructive. Beyond Social Democracy, there were three major political movements, which reflected the main sociocultural divisions (milieux) in society: (political) Catholicism, (Protestant) liberalism, and (Protestant) conservatism (Lepsius 1973). The Zentrum had already supported social reforms since its Soester Programm from 1870. The Conservatives saw the disruptions of the traditional order by marketization as something that should be countered through social policy, as documented for instance in the Tivoli Programm from 1892. The only clear exception regarding this lack of opposition was the small Liberal Party Liberale Vereinigung (also known as Sezession), a party that splintered from the bigger right wing of liberalism (National Liberals) in 1880 before joining the Deutsche Freisinnige Partei (also called Freisinn) in 1884. The National Liberals, for their part, were extremely ideologically heterogeneous and had broken with most of the political and economic ideas that defined liberalism in the preparliament in 1848; this was most notable with the legislative support of Bismarck's culture war (Kulturkampf) against the Catholic Church and the Zentrum, as well as the protectionist turn after the 1873 crisis.

As hinted at previously, there was an additional, related incentive for the "establishment" to implement social insurance programs: The growing discussion of the "social" or "worker question" was also one of employer liability and the preemptive protection of laborers. Major industry associations (like the Central Association of German Industry [CDI]) and factory owners-including Bismarckpreferred the insurance model, arguing that it would be the more efficient way to address the problem pressure (QGDS 2.5; Reidegeld 2006: 190). In that sense, the three new programs can be seen as the component parts of a successful depoliticization effort, as they alleviated pressure on employers to improve the preemptive protection of workers.

But noting the reasons for and existence of broad prosocial policy stances only takes us so far. As important as attitudes toward social reforms per se were, we must also consider the organizational component and the shifting context within which they were being debated. Crucial here is the increasing acceptance of the new political order and the federal government as central authority. By the early 1880s, 
even federal parties like Zentrum, with its formerly bitter anti-Prussian rhetoric, had made their peace with the federal government. The National Liberal Party even became part of the state-building coalition of Bismarck, at least until the election defeat of 1878 that marked the transition from the liberal electoral support base of Bismarck to a Catholic-conservative one. This widening commitment to the Reich was key, as it had been acknowledged since the pauperism debates that forging national allegiances was a complementary purpose of social policy (Reidegeld 2006: 24).

Overall, the combination of the preceding factors explains the need for social policy legislation and the considerable pressure under which it was negotiated and implemented. This latter characteristic, in turn, explains the (unintended) hybrid status of the new schemes. A broad alliance existed in support of a social policy response to the thus far unaddressed consequences of rapid industrialization. The end of the so-called culture war with the Zentrum after 1878 (when Bismarck began to fight against the Social Democrats) opened a window of opportunity. In addition, the assassination of the Russian tsar and the US president in 1881 contributed to a climate that observers perceived to be favorable for social reforms (Pflanze 2008: 407). This seems especially plausible because attempts to assassinate Emperor Wilhelm and Bismarck were seen to be an expression of growing hostility toward the state within the labor movement. To explain the specific nature of the implemented programs, however, we must also consider the political constellation and the processes underlying the different outcomes vis-à-vis the three key programs introduced.

\section{Political Processes and Legislative Outcomes}

We have established that the unmet problem pressure and the interests of the actors within a context of asymmetric federalism were important conditions for the new legislation. So how did the political process play out?

Bismarck and his staff acknowledged that the social question had become pressing as early as the 1860 s, even producing a white paper on social insurance as a potential solution in 1866 and holding a conference on the subject in 1871 (Reidegeld 2006: 162-64, 174-75). During the founding years of the Reich, Bismarck repeatedly expressed his wish to make workers "clients of the state" (ibid.: 175-76). Within the Prussian ministerial bureaucracy, the issue of social insurance became salient in 1878, and some high-profile bureaucrats such as Theodor Lohmann, then the Trade Undersecretary, pushed for reform (Pflanze 2008: 406).

All three programs under discussion were then announced in the imperial declaration of November 17, 1881. When the window of opportunity opened after the end of the culture war with the Zentrum, pivotal political forces and even organized business were amenable to the idea of insurance as such. While they agreed that it was necessary to improve the social situation of the proletariat, its organization and the degree of centralization were contentious. 
Examining the drafting, revising, and passing of the three main pieces of social legislation (with a focus on parties and interest groups) provides us with additional insights into this process.

\section{Accident Insurance Law}

Accident insurance was introduced in 1884 , in the process initiating a dramatic move away from liability law traditions in Germany (Moses 2009: 240). The structure of the program, however, was quite different from what Bismarck had initially envisioned; his original plan would have seen the Reich cover benefits for lower-paid workers, who would have been exempted from making their own contributions to the plan (Hennock 2007: 90). The program is particularly instructive given its political importance, with the sick pay scheme (despite being passed by parliament earlier) only playing a complementary role.

Despite the centralizing effects of the accident insurance legislation (Unfallversicherungsgesetz [UVG]), it met little resistance in the Bundesrat. Only the small liberal Freisinn party rejected the insurance proposal as state interventionism in the 1880s. In particular, they criticized the compulsory nature of the insurance, the exclusion of private schemes, its unitary structure, and the (co-)financing by the Prussiandominated federal government. Rather than a centralized insurance body (the Reichsversicherungsamt), they argued that there should be one insurance fund per state.

The latter sentiment was shared by the Zentrum, which became pivotal after Bismarck's split with the Liberals (initially the quasigovernment party) after 1878. Faced with this opposition, Bismarck dismissed the idea of creating state agencies and favored cooperative and sector-specific risk pooling. The introduction of this cooperative and corporate rhetoric and organization rendered the suggestions acceptable to the Zentrum, as they appealed to their ideals of a corporative state (Reidegeld 2006: 201). However, Bismarck nevertheless maintained the federal supplement component, which he considered crucial for his ambition to create "state pensioners."

The far-reaching changes necessary for the law to pass after two rejections in parliament are most easily understood by looking at the sequence of titles for the new insurance body (ibid.: 199-200). Bismarck's initial preference, the Reichsversicherungsamt, simply meant "Imperial Insurance Office." As the Zentrum opposed this idea, it did not even make it into the first draft. Rather, the first draft suggested insurance funds in each of the states, the Länderversicherungsanstalten. The Betriebsgenossenschaften (company insurance associations) from the second draft then became the rather independent Berufsgenossenschaften (occupational insurance associations) in the third. Finally, the supplement from the Reich was removed as well, with only a guarantee (Reichsgarantie) in case the occupational funds were dissolved or insolvent. The law then passed with 152 votes in the Reichstag in favor and 77 against. While the immediate political goal to introduce the scheme was finally realized, the price was far-reaching concessions regarding its organization and structure.

In terms of policy outcomes, the introduction of a waiting period of 13 weeks for the benefits of the employer-financed program effectively shifted responsibility to 
sickness insurance funds and thus to the employees paying the contributions. In accordance with the depoliticization rationale of the economic elites, however, compensation as a principle prevailed over prevention (with the inadequate liability law still mainly in effect) (ibid.: 202).

\section{Sickness Insurance Law}

The introduction of basic sick pay was less contentious than accident insurance, and it was widely viewed as a necessary counterpart to the Accident Insurance Law (Hennock 2007: 157). These funds were not financed by the Reich, but rather were contribution based, relying on equal contributions from employees and employers (Weindling 1991: 196-97). The benefit was designed to cover medical services to insure workers and their dependents and offered nominal cash payouts to compensate for income loss during sickness (Bleses and Seeleib-Kaiser 2004: 15).

There is little evidence of significant conflict between the states and the Reich regarding this legislation (Krankenversicherungsgesetz [KVG]), likely because the program did not involve any funding from the central government and was administered by self-governing, regionally-organized funds. Perhaps most importantly, though, sick-pay legislation was viewed as an incidental by-product of the 13-week waiting period for accident insurance, and one that merely extended and codified preexisting principles (Frohman 2008: 104; Hennock 2007: 157). Indeed, Lohmann introduced the long wait time into the UVG draft without Bismarck's knowledge partly in the hopes that it would create "irreversible" political pressure to act (Reidegeld 2006: 207).

The law was also less controversial because it built on the existing Kassenwesen, bringing it closer in line with Lohmanns's corporatist ideas while still alleviating the aforementioned problems regarding labor mobility and eligibility. It was thus passed with a large majority (216 to 99). Membership in independent funds (freien Hilfskassen) was still possible despite opposition from the CDI, but now under stricter supervision. Nevertheless, by 1891 the independent funds had amassed almost a million members. The Hilfs (auxiliary) and Orts (local) Kassen remained a stronghold for the self-administration and autonomy of labor.

\section{Disability and Pension Law}

An old-age and disability insurance scheme was the last of our programs to be introduced, and was also the most controversial (Frohman 2008: 104). Unlike the previous programs, it was subsidized by the Reich, although the majority of the funding was still derived from contributions (Reidegeld 2006: 207). Here the dispute with the states arose over who would administer the insurance; evidently, the states were no longer opposed to federal funding of social insurance schemes so long as they were the ones administering the programs.

The federal government's initial proposal held that the largely self-governing administrative Berufsgenossenschaften, which was responsible for administering accident insurance, should oversee the new scheme (Hennock 2007: 188). When 
the proposal went to committee in the Bundesrat, however, Bavaria spearheaded an initiative to move the administration of the program to the state level (Hennock 2007: 188). While Prussia could have pushed to reject the committee's proposal in favor of the centralist alternative, Bismarck was not so averse to the change to risk antagonizing the medium-sized states that supported the reform. Both the Berufsgenossenschaften- and state-based administrative proposals were thus allowed to go to the Reichstag (ibid.: 188-89). Yet while particularist state interests may not have had a majority in the Reichstag, an outside actor intervened: The CDI was opposed to any increases in the power and size of the Berufsgenossenschaften, which it viewed as a "potential rival for the ear of government," and therefore leveraged its influence to ensure the adoption of the state-based proposal (ibid.: 189).

Ultimately, the legislation (Gesetz betreffend die Invaliditäts- und Altersversicherung [IVG]) was rather narrowly passed (185 against 165 votes) on June 22, 1889 with the support of the Conservatives, the National Liberals, and, importantly, parts of the Zentrum. Freisinn and the SAPD, as with the other social insurance laws, voted against the proposal. It seemed questionable whether the law would pass at all prior to the vote, as it had less popular and employer support than the previous two schemes and enjoyed less public backing from Bismarck (whose position was weakened by Wilhelm's death in 1888).

\section{Summary}

Laying out the political processes behind the introduction of these three programs provides evidence of shared pressures and dynamics. Nevertheless, some differences remain, most notably regarding the support for and timing of the pension law. The labor market pressure to introduce accident and sickness insurance was more consensual among the pivotal actors than Bismarck's state-building goal of creating pensioners of the state (QGDS 2.6: XVIII-XX). In other words, proximity to the "objective" labor market pressure influenced the willingness of the actors to compromise on program design. We argue that both the delay in the legislative process and the comparatively narrow margin with which the IVG law was passed reflects not only the weakened position of Bismarck but also that the legislation was considered less pressing.

Looking across the broader social policy project, two particular goals of Bismarck united the various legislative attempts. First, he aimed to create programs that were organized and financed by the central state, in the process enhancing the federal government's role within the empire. Second, there was an aspiration to turn workers into clients of the state and ensure that the state was not perceived to be simply the agency of the bourgeoisie.

When we consider these "subjective" political aims and ambitions of Bismarck, the structure and design of the programs left much to be desired. In particular, the organization of the funds remained far more independent from the central state than he had envisioned. 


\section{Discussion}

Despite the presence of certain German peculiarities, examining the origins of German social insurance legislation offers several lessons that advance our understanding not only of social program introduction, but also of radical social policy innovation more broadly.

First, institutional context is clearly indispensable in understanding the eventual response to problem pressure, as the role of Prussia in the Bundesrat significantly altered the rules of the federal game. Indeed, it is difficult to understand the previously mentioned developments without reference to Germany's asymmetric federalism. But we must nevertheless look beyond the institutional context to understand the nature and timing of reform.

This brings us to our second conclusion: that an existential threat to both the viability of the labor market and the German state in its then existing form was a necessary (though not sufficient) precondition of reform. A rapid increase in problem pressure thus created an "objective" (in the sense described in the preceding text) impetus to act that helped to overcome some of the potential obstacles to program introduction. In particular, rapid industrialization and urbanization were leading to signs of unrest and class conflict that were increasingly difficult to ignore, with results reminiscent of a Polanyian "double movement" (Polanyi 1944). In addition, industrialization entailed a growing number of cases of workplace accidents, and vague legislation on the matter made it unclear who would be held liable. Taken together, these factors resulted in severe labor market- and state-building pressure.

Third and contrary to Becker's (1988) theoretical position, adjustment to this existential threat did not come in the form of a societal process of trial and error. Key here was the underlying and widespread belief that the extension or marginal reform of the existing system would have been inadequate-a position shared across most of the political spectrum and by many industrialists. Indeed, the preexisting organizations that could potentially have acted to relieve this pressure- the Kassenwere viewed as problematic in a variety of ways: Not only were they largely incapable of dealing with the scope of the problem or facilitating the movement of persons, but they were also viewed as political threats aligned with the labor movement. Consequently, failing to introduce radical reform was viewed rather broadly across the political spectrum as undermining the existing system and playing into the hands of the Social Democrats.

At the same time, however, this goal-oriented action, purposively directed at addressing the existential threat, was not really of the authoritarian form laid out by Becker either. Instead, it shared some of the characteristics he points to in describing trial and error processes-namely, accommodation and compromise. Here we have evidence contradicting what Becker (ibid.: 879) argued was the most important barrier to goal-directed action: Actors do indeed seem to have "take[n] into account not only their special interests but at the same time ... those existential conditions that affect everyone." This is clearest when looking at the relationship between the 
federal government and the various schemes. Regarding both the organization and the funding, Bismarck had to adjust the draft legislation to the more particularistic and corporatist ideas of Liberals, Conservatives, and especially the Zentrum. This led to relatively independent and only partly state-financed schemes, not the state socialism he had initially sought. Compromise on "subjective" goals occurred alongside the addressing of "objective" problem pressure.

\section{Conclusion}

This article has explored the origins of nineteenth-century German social insurance legislation to stress the potential importance of "objective" problem pressure. Through this investigation, we have sought to supplement recent empirical applications of open functional reasoning (e.g., Becker 2009; Van Kersbergen and Vis 2013). We began by asking how we can best understand social program introduction and proceeded to explore the case with two goals in mind. First, we argued that the case study points to an important blind spot in much contemporary research in political science and sociology-namely, the importance of "objective" problem pressure, where "objectivity" is defined by an existential threat to the system. In making this case, we laid out the theory of open functional reasoning and contrasted it with functionalism.

Second and relatedly, we used the implications of the case study to further refine the open functional approach. By moving away from the existing literature's focus on gradual change and instead focusing on radical policy innovation, we are led to draw conclusions that extend our understanding of the relationship between "objective" problem pressure and reform. In particular, the investigation suggests that goal-oriented action may be more common and more prone to compromise than the theory posited, and we pointed to factors that help us to understand how this outcome unfolded.

In laying out this explanation, we concentrated on several interrelated contextual elements. Most broadly, we cannot ignore the fact that the overarching institutional setup must be considered-leading us in this instance to highlight the role of asymmetric federalism. But it would be a mistake to simply conclude that "institutions matter" and move on. To properly understand radical policy innovation in latenineteenth-century Germany, one must also consider the intensity of the "objective" problem pressure and the specific constellation of party interests. The high problem pressure precipitated a far-reaching consensus about the necessity of social insurance, which explains why the innovative social insurance programs were introduced at all.

Yet Bismarck could not simply act alone, and he lacked the partners needed, both in and out of the Reichstag, to implement the "state-socialist" schemes he envisioned. The employers and industrialists, alongside the Conservatives and especially the Zentrum, were opposed to this approach, and even high-ranking members of the ministerial bureaucracy preferred more independent insurance bodies with less direct state funding. 
Overall, these findings point to the importance of considering not only gradual policy adjustment to "objective" problem pressure but also instances of radical social policy innovation. This suggests several avenues for future research. In addition to investigating the extent to which "objective" problem pressure has been a key factor behind other radical policy innovations, future studies might work to uncover the conditions under which: (1) the policy response is more likely to successfully address the underlying pressure; (2) a consensus response is more likely to emerge among key actors; and (3) conscious goal-directed action is more likely to occur.

All of which brings us back to our central point: To understand social policy reform without a serious consideration of problem pressure would, in some instances, be to miss a key part of the story. While functionalism has clear and obvious problems as a theory, excluding functional reasoning a priori from one's analysis diminishes our ability to explain political developments in the real world.

1 This implies that agents, through their choices, help to shape the system, potentially even setting in motion future existential crises. As such, the material context is not entirely independent of human action, but this does little to change the point—contra certain constructivists (e.g., Hay 2011)—that such crises exist independently of human understanding.

2 Another important facet of the institutional context was that, although a parliamentary majority was needed to pass (most) legislation, chancellors were not dependent on the confidence of parliament until October 1918.

${ }^{3}$ Consult the appendix for further details on all QGDS sources.

\section{Appendix}

Sources from the Quellensammlung zur Geschichte der Deutschen Sozialpolitik 1876-1914.

In what follows, we delineate the specific primary source document references taken from the Quellensammlung zur Geschichte der Deutschen Sozialpolitik 1876-1914 (QGDS). Note that an in-text reference to QGDS 1.2: 20, for example, refers to source No. 20 in the second volume (Band) of the first section (Abteilung). If a number is not listed, the reference is to the introductory text.

QGDS 1=Quellensammlung zur Geschichte der Deutschen Sozialpolitik 1876-1914. I. Abteilung. Von der Reichsgründungszeit bis zur Kaiserlichen Sozialbotschaft (1867-1881). Wolfgang Ayaß, Darmstadt.

1. Band: Grundfragen staatlicher Sozialpolitik. Die Diskussion der Arbeiterfrage auf Regierungsseite vom preußischen Verfassungskonflikt bis zur Reichstagswahl von 1881 (1994)

- No. 107: Brief des Regierungsrates Theodor Lohmann an den Prinzenerzieher Dr. Ernst Wyneken (May 19, 1872)

- No. 157: Rede des Reichskanzlers Otto Fürst von Bismarck im Deutschen Reichstag (September $17,1878)$

2. Band: Von der Haftpflichtgesetzgebung zur ersten Unfallversicherungsvorlage (1993)

- No. 20: Eingabe der Magdeburger Allgemeinen Versicherungs AG an das Reichskanzleramt (September 12, 1878)

- No. 21: Der Arbeitgeber Nr. 1131. Versicherungsgesellschaft contra Versicherung (January $4,1878)$ 
- No. 17: Denkschrift zur Revision des Haftplfichtgesetzes vom 7.Juni 1871 mit drei alternativen Gesetzentwürfen für den preußischen Handelsminister Dr. Heinrich Aschenbach (January 31, 1878)

- No. 29: Schreiben des stellvertretenden preußischen Handelsministers Albert Mayback an den preu/ischen Minister des Innnern Graf Bootho zu Eulenburg (May 2, 1879)

- No. 56: Brief des Kommerzienrats Louis Baare an die Direktion der Allgemeinen Unfallversicherungsbank Leipzig (April 10, 1880)

- No. 57: Promemoria des Kommerzienrats Louis Baare für den preu/ischen Handelsminister Karl Hofmann (April 30, 1880)

- No. 83: Sitzungsprotokoll des Staatsministeriums (August 28, 1880)

- No. 117: Brief des Kommerzientrats Louis Baare an den Fabrikanten Ludwig Kretschmar (October 15, 1880)

- No. 123: Brief des Geheimen Oberregierungsrates Theodor Lohmann an den Schuldirektor Dr. Ernst Wyneken (October 23, 1880)

3. Band: Arbeiterschutz (1996)

- No. 136: Entschliessung der siebten ordentlichen Generalversammlung des Vereins zur Wahrung der gemeinsamen wirtschaftlichen Interessen in Reinland und Westfalen (November 7, 1877)

- No. 201: Eingabe des Zentralverband Deutscher Industrieller an den Bundesrat (March 17, 1881)

5. Band: Gewerbliche Unterstützungskassen (1999)

6. Band: Altersversorgungs- und Invalidenkassen (2002)

7. Band: Armengesetzgebung und Freizügigkeit (2000)

8. Band: Grundfragen der Sozialpolitik in der öffentlichen Diskussion: Kirchen, Parteien, Vereine und Verbände (2006)

QGDS 2=Quellensammlung zur Geschichte der Deutschen Sozialpolitik 1876-1914. II Abteilung. Von der kaiserlichen Sozialbotschaft bis zu den Februarerlassen Wilhelms II (1881-1890). Wolfgang Ayaß, Darmstadt.

1. Band: Grundfragen der Sozialpolitik. Die Diskussion der Arbeiterfrage auf Regierungsseite und in der Öffentlichkeit (2003)

3. Band: Arbeiterschutz (1998)

5. Band: Die gesetzliche Krankenversicherung und die eingeschriebenen Hilfskassen (2009)

- No. 1: Denkschrift des Geheimen Oberregierungsrates Theodor Lohmann (September 3, 1881)

6. Band: Die gesetzliche Invaliditäts- und Altersversicherung und die Alternativen auf gewerkschaftlicher und betrieblicher Grundlage (2004)

\section{References}

Abbott, Andrew, and Stanley DeViney (1992) "The welfare state as transnational event: Evidence from sequences of policy adoption." Social Science History 16 (2): 245-74.

Abrams, Lynn (2006) Bismarck and the German Empire: 1871-1918. London: Routledge.

Alber, Jens (1988) "Continuities and changes in the idea of the welfare state." Politics and Society 16 (4): 451-68.

Baldwin, Peter (1990) The Politics of Social Solidarity: Class Bases of the European Welfare State, 18751975. Cambridge: Cambridge University Press. 
Becker, Uwe (1988) "From social scientific functionalism to open functional logic." Theory and Society 17 (6): 865-3.

- (2007) "Open systemness and contested reference frames and change: A reformulation of the varieties of capitalism theory." Socio-Economic Review 5 (2): 1-26.

- (2009) Open Varieties of Capitalism: Continuity, Change and Performances. Basingstoke, UK: Palgrave Macmillan.

Béland, Daniel (2005) "Ideas and social policy: An institutionalist perspective." Social Policy and Administration 39 (1): 1-18.

Bleses, Peter, and Martin Seeleib-Kaiser (2004) The Dual Transformation of the German Welfare State. New York: Palgrave.

Campbell, John L. (2002) “Ideas, politics, and public policy.” Annual Review of Sociology 28 (1): $21-38$.

Craig, Gordon A. (1999) Germany: 1866-1945. New York: Oxford University Press.

Crouch, Colin, and Henry Farrell (2004) "Breaking the path of institutional development? Alternatives to the new determinism." Rationality and Society 16 (1): 5-43.

Demerath, Nicholas J. (1966) "Synecdoche and structural-functionalism." Social Forces 44 (3): 390-401.

Deutsches Historisches Museum (2010) Sicher Arbeiten -125 Jahre Gesetzliche Unfallversicherung In Deutschland 1885-2010. Berlin.

Deutsches, Reich (1871) Reichsgesetzblatt Nr. 25. Berlin, Germany.

Frohman, Larry (2008) Poor Relief and Welfare in Germany from the Reformation to World War I. New York: Cambridge University Press.

Hacker, Jacob S. (1998) "The historical logic of national health insurance: Structure and sequence in the development of British, Canadian, and US medical policy." Studies in American Political Development 12 (1): $57-130$.

Hall, Peter A. (1993) "Policy paradigms, social learning and the state: The case of economic policy in Britain." Comparative Politics 25 (3): 275-96.

Hall, Peter A., and Kathleen Thelen (2009) "Institutional change in varieties of capitalism." SocioEconomic Review 7 (1): 7-34.

Hay, Colin (2011) "Ideas and the construction of interests." in Daniel Béland and Robert Henry Cox (eds.) Ideas and Politics in Social Science Research. Oxford: Oxford University Press: 65-82.

Hennock, E. P. (2007) The Origin of the Welfare State in England and Germany, 1850-914. Cambridge: Cambridge University Press.

Hentschel, Volker (1978) Wirtschaft und Wirtschaftspolitik im wilhelminischen Deutschland. Organisierter Kapitalismus und Interventionsstaat. Stuttgart: Klett-Cotta.

Hoffmann, Walther G. (1965 [2006]) Das Wachstum der deutschen Wirtschaft seit der Mitte des 19. Jahrhunderts. GESIS, GER, ZA8256 Datenfile Version 1.0.

Kiesewetter, Hubert (1989) "Regionale Lohndisparitäten und innerdeutsche Wanderungen im Kaiserreich." in Jürgen Bergmann, Jürgen Brockstedt, Rainer Fremdling, Rüdiger Hohls, Hartmut Kaelble, and Hubert Kiesewetter (eds.) Regionen im historischen Vergleich: Studien zu Deutschland im 19. und 20. Jahrhundert: Westdeutscher Verlag: 133-99.

Korpi, Walter (1989) "Power, politics, and state autonomy in the development of social citizenship: Social rights during sickness in eighteen OECD countries since 1930." American Sociological Review 54 (3): 309-28.

Lepsius, Rainer M. (1973) "Parteiensystem und Sozialstruktur. Zum Problem der Demokratisierung der deutschen Gesellschaft." in Gerhard A. Ritter (ed.) Deutsche Parteien vor 1918. Köln: Kiepenheuer and Witsch: 56-80.

Luhmann, Niklas (1984) Soziale Systeme: Grundriss Einer Allgemeinen Theorie. Frankfurt, Germany: Suhrkamp.

Manow, Philip (2005) "Germany: Cooperative federalism and the overgrazing of the fiscal commons." in Herbert Obinger, Stephan Leibfried, and Francis G. Castles (eds.) Federalism and the Welfare State: New World and European Experience. New York: Cambridge University Press: 222-62. 
Mares, Isabela (2001) "Firms and the welfare state: When, why and how does social policy matter to employers?" in Peter A. Hall and David Soskice (eds.) Varieties of Capitalism: The National Foundations of Comparative Institutional Advantage. Oxford: Oxford University Press: 184-212.

Moses, Julia (2009) "Accidents at work, security and compensation in industrialising Europe: The cases of Britain, Germany and Italy, 1870-1925.” Jahrbuch fur Recht und Ethik 17: 237-57.

North, Michael (2005) Deutsche Wirtschaftsgeschichte. Ein Jahrtausend im Überblick. Munich: C. H. Beck. Parsons, Talcott (1977) Social Systems and the Evolution of Action Theory. New York: The Free Press. Pedersen, Susan (1995) Family, Dependence, and the Origins of the Welfare State: Britain and France, 1914-1945. Cambridge: Cambridge University Press.

Pflanze, Otto (2008) Bismarck Bd. 2: Der Reichskanzler. Munich: C.H. Beck.

Polanyi, Karl (1944) The Great Transformation: The Political and Economic Origins of Our Time. Boston: Beacon Press.

QGDS 1: Quellensammlung zur Geschichte der Deutschen Sozialpolitik (1876-1914). I. Abteilung. Von der Reichsgründungszeit bis zur Kaiserlichen Sozialbotschaft (1867-1881). Wolfgang Ayaß: Darmstadt.

QGDS 2: Quellensammlung zur Geschichte der Deutschen Sozialpolitik (1876-1914). II Abteilung. Von der kaiserlichen Sozialbotschaft bis zu den Februarerlassen Wilhelms II (1881-1890). Wolfgang Ayaß: Darmstadt.

Reidegeld, Eckhart (2006) Staatliche Sozialpolitik in Deutschland. Band I: Von den Ursprüngen bis zum Untergang des Kaiserreiches 1918. Wiesbaden: Springer VS.

Rimlinger, Gaston V (1966) "Welfare policy and economic development: A comparative historical perspective." The Journal of Economic History 26 (4): 556-71.

Ritter, Gerhard Albert (1986) Social Welfare in Germany and Britain: Origins and Development. New York: Berg Publishers.

Robertson, David Brian (1993) "The return to history and the new institutionalism in American political science." Social Science History 17 (1): 1-36.

Rosenberg, Hans (1967) Große Depression und Bismarckzeit: Wirtschaftsablauf, Gesellschaft und Politik in Mitteleuropa. Munich: de Gruyter.

(1943) "Political and social consequences of the Great Depression of 1873-1896 in Central Europe." The Economic History Review 13 (1-2): 58-73.

Schmitt, Carina, Hanna Lierse, Herbert Obinger, and Laura Seelkopf (2015) "The global emergence of social protection explaining social security legislation 1820-2013.” Politics and Society 43 (4): 503-24.

Spree, Reinhard (1978 [2003]) Wachstumstrends und Konjunkturzyklen in der deutschen Wirtschaft von 1820 bis 1913. GESIS, GER, ZA8053 Datenfile Version 1.0.

Steinberg, Jonathan (2011) Bismarck: A Life. Oxford: Oxford University Press.

Van Kersbergen, Kees, and Barbara Vis (2013) Comparative Welfare State Politics. Cambridge: Cambridge University Press.

Vis, Barbara, and Kees Van Kersbergen (2013) "Towards an open functional approach to welfare state change: Pressures, ideas, and blame avoidance." Public Administration 91 (4): 840-54.

Wehler, Hans Ulrich (1969) Bismarck und der Imperialismus. Köln: Kiepenheuer u: Witsch.

Weindling, Paul (1991) "The modernization of charity in nineteenth-century France and Germany." in Jonathan Barry, and Colin Jones (eds.) Medicine and Charity before the Welfare State. London: Routledge: 190-206.

Wilensky, Harold L. (1975) The Welfare State and Equality. Berkeley: University of California Press.

Wilensky, Harold L., and Charles N. Lebeaux (1959) Industrial Society and Social Welfare: The Impact of Industrialization on the Supply and Organization of Social Welfare Services in the United States. New York: Russell Sage Foundation.

Ziblatt, Daniel. (2006) Structuring the State: The Formation of Italy and Germany and the Puzzle of Federalism. Princeton, NJ: Princeton University Press. 